\title{
Q/A on Teaching Credit Classes for Entrepreneurship Research
}

By: Sarah Barbara Watstein, Mary G. Scanlon, and Steve Cramer

Watstein, S.B., Scanlon, M.G., and Cramer, S. (2015). Q/A on Teaching Credit Classes for Entrepreneurship Research. Reference Services Review, 43(3): 480-490.

https://doi.org/10.1108/RSR-06-2015-0030

(C) 2015, Emerald Group Publishing Limited. This author accepted manuscript is deposited under a Creative Commons Attribution Non-commercial 4.0 International (CC BY-NC) license. This means that anyone may distribute, adapt, and build upon the work for noncommercial purposes, subject to full attribution. If you wish to use this manuscript for commercial purposes, please contact permissions@emerald.com

\begin{abstract}
:
Purpose: The purpose of this paper is to present the question and answer $(\mathrm{Q} / \mathrm{A})$ to provide an opportunity for two seasoned academic business librarians to share their experiences with courses in entrepreneurship in their universities. Design/methodology/approach: Question and answer. Findings: The evolving business school curricular landscape, and especially an increase in courses in entrepreneurship, presents unique opportunities for engagement, visibility and centrality for academic business librarians. Originality/value: Entrepreneurship is increasingly valued in today's world. To be successful, entrepreneurs must successfully deal with and navigate a highly complex information landscape. Academic business librarians are positioned to help student, faculty and future entrepreneurs alike learn the skills to successfully traverse this landscape.
\end{abstract}

Keywords: academic libraries | information management | undergraduates | information literacy

\section{Article:}

\section{Introduction}

Courses in entrepreneurship at the college and university undergraduate level are an increasing part of the business school curricular landscape. At the same time, colleges or universities with majors or minors in entrepreneurship, entrepreneurial studies or small business are also on the rise. This rapidly evolving curricular context provides opportunities for academic business librarians to offer for-credit classes for business or non-business students who major, minor or concentrate in this area.

The following question and answer $(\mathrm{Q} / \mathrm{A})$ explores the experiences of two academic business librarians - Steve Cramer, Business Librarian \& Coleman Fellow for Entrepreneurship Education, University of North Carolina at Greensboro (UNCG) and Mary G. Scanlon, Research and Instruction Librarian for Business \& Economics at Wake Forest University (WFU). 
Biographical information about our interviewees frames the $\mathrm{Q} / \mathrm{A}$, and is followed by descriptive information about each institution.

Cramer works at Jackson Library, a general library several all schools and departments on campus except music. This is his third library position, and all have involved some level of business information support. He has been at UNCG since 2001, began serving as a professional librarian at Davenport College (now University) in Holland, Michigan in 1995, and also has also worked at Duke University in Durham, NC. Steve is the co-founded of Business Librarianship in North Carolina (BLINC) and a member of BRASS. He has been writing and speaking about coteaching embedded librarianship, as well as liaison reorganization. He blogs at http://liaisonlife.wordpress.com. He can be reached at smcramer@uncg.edu.

Scanlon holds the academic rank of Librarian. She earned her MBA at the Weatherhead School of Management at Case Western Reserve University, and her MLIS at Kent State University. Before coming to WFU, she spent 20 years in a variety of marketing positions in the corporate world. Since coming to WFU in 2004, she has been serving as liaison to the undergraduate business and MSA programs in the School of Business along with the Department of Economics and the minor in Entrepreneurship and Social Enterprise. She is embedded in the School of Business while reporting into the Z. Smith Reynolds Library, the main campus library. She has helped organize several successful conferences including the "Conference for Entrepreneurial Librarian" series. In addition, she has written and edited several publications, including the 2012 publication The Entrepreneurial Librarian: Essays on the Infusion of Private-Business Dynamism into Professional Service from McFarland, Inc. For the past four years, she has served as Chair of Business Librarianship in North Carolina (BLINC), a section of the North Carolina Library Association, which was co-founded by Steve Cramer. She can be reached at scanlomg@wfu.edu

\section{University of North Carolina at Greensboro (UNCG)}

UNCG is the third oldest University of North Carolina (UNC) campus. It was the state's women's college at a time when female students were not allowed into the other two campuses. An urban campus with around 18,000 students, UNCG is the largest and most diverse university in the Triad. It offers 79 undergraduate programs in over 100 areas of study, 72 masters programs and 27 doctoral programs. Its character is reflected in this statement - "The University of North Carolina at Greensboro is a challenging, supportive and engaged community where learning is carried forward to Do something bigger altogether ${ }^{1}$ ".

\section{Wake Forest University}

WFU is a private, co-educational, residential university located on 340 acres in Winston Salem, NC. For the 2014-2015 academic year, its enrollment of 7,591 comprised 4,812 undergraduate and 2,779 graduate and professional school students. Wake Forest is made up of six schools. Its graduate programs include the School of Law, School of Business, School of Divinity and School of Medicine, while undergraduates are enrolled in either Wake Forest College or the

\footnotetext{
${ }^{1}$ www.uncg.edu/inside-uncg/inside-glance.htm (accessed 15 June 2015).
} 
business school. In its 2015 edition, US News' Best Colleges ranked WFU at \#27. The university's mission is "Pro Humanitate" or for humanity.

\section{$\mathbf{Q} / \mathbf{A}$}

1. Describe the targeted for-credit instruction courses that you provide at your respective institutions. Specifics pertaining to pedagogy, design, outcome and assessment would be of interest to our readers. At the same time, help our readers out with some background - what was the context for your decision(s) to proceed in this fashion?

Cramer: This takes a bit of back story, sorry. For many years, I have been co-teaching a research-intensive export marketing class required for marketing majors. Partnering with the professor of that class has been very rewarding and fruitful (including some co-authored articles and an entrepreneurial venture that is finally getting somewhere). Meanwhile, UNCG hired a new professor of entrepreneurship, Dianne Welsh, who then created our cross-campus entrepreneurship program. That fast-growing program has now won many national awards: http://bae.uncg.edu/ecdp/category/awards/

At first, I supported Professor Welsh's classes with guest teaching and consulting, including her ENT 300: "Feasibility Analysis: From Idea to Opportunity" (a prerequisite for ENT 336: "Business Plan: From Opportunity to Action" - both are required for all entrepreneurship majors and minors). But I wanted a deeper relationship with her and the ENT students, and so worked my way into being embedded into ENT 300 as the second co-teaching gig. (I wrote a book chapter about this, available at: https://liaisonlife.wordpress.com/2014/09/12/bookchapter_in_ir/

After a couple of years of helping teach that class, Professor Welsh invited me to be a Coleman Fellow for Entrepreneurship Education at UNCG. The Coleman Foundation (www.colemanfoundation.org/) funds a fellowship program, in which faculty from outside business schools creates entrepreneurship classes, or infuses entrepreneurship principles into an existing class. The Foundation's goal is to promote self-employment across all academic subjects, and not just among traditional business students. For example, arts entrepreneurship is now huge at UNCG. UNCG usually has three new Coleman fellows each year.

New Coleman fellows attend a national summit in Chicago for workshops and peermentoring on teaching entrepreneurship, and then attend monthly online workshops for the rest of the school year. They have to teach their class at least once a year and submit occasional reports to the Fellow's web site. I am now a "veteran fellow" who co-presents at the summit each year, and helps to run the UNCG Coleman Fellows program as Professor Welsh's assistant director. There is more about my Coleman Fellow experiences at: https://liaisonlife.wordpress.com/category/coleman-fellow/

For my "Coleman class", I recruited the LIS and GEO departments to be my original crosscampus listings along with ENT. (The "economic development" a part of my class title is a nod to Geography, which has a track on regional economic development.) Professor Welsh and I wanted the class to be available to graduate students, as well as undergraduates, hence 
the 500-level status. That meant I had to submit the paperwork for the UNCG undergraduate, as well a graduate curriculum committees, after first going through the departmental and school-level committees (six curriculum committees total, yikes!).

Scanlon: I teach two for-credit classes: LIB230 Business and Accounting Research Sources and Strategies, and LIB235 Research Methods for Entrepreneurs. LIB235 is the newer class; I began teaching it in the spring of 2014. It's designed for students pursuing a minor in Entrepreneurship and Social Enterprise (ESE), the largest and fastest growing minor in the College, which launched in spring 2009. In addition, it serves students in the School of Business pursuing a specialization in New Business Development within the Business and Enterprise Management major. In the College, LIB235 counts as an elective toward the ESE minor.

The central organizing principle of LIB235 is the business plan, an essential document for entrepreneurs. Using a case study approach, students learn how to perform the secondary research pertaining to industry, company and market research and write the executive summaries for each section. Students are given a choice between one of two imagined new companies: a food truck or a microbrewery. Their research for the class is centered on that company as if they were preparing a business plan for it. The reason I restrict the class to two pre-approved concepts is so that I can make sure each type of resource is available, so students will be able to complete all the worksheets and assignments.

My goal is to teach students the process of conducting research and the skills associated with effective searching along with a familiarity with the business planning process. I use an active learning approach: for each class I develop a set of learning outcomes and a worksheet. I begin class by reviewing the learning outcomes, placing them in context of the business plan and the class, demonstrating each database and conducting some discussions and reviews of the databases, but most of the class time is spent on the worksheets. I circulate through the room - class size is limited to 15 students - and I look at each student's work, ask questions and clarify anything that's unclear. Periodically, I stop the class to conduct discussions on their database explorations, ask them to compare and contrast the resources and apply the information to their new companies.

Near the beginning of the semester, I discuss Bloom's Taxonomy. As we move through the semester, I refer to it regularly, asking students at what level in the taxonomy a particular question resides. I alert them when a question is asking them to evaluate or analyze rather than just remember.

Learning outcomes are provided for the entire class, but as I've said, I also identify them for each class session. Their worksheets and executive summaries are graded, and I give a series of quizzes. Using these tools along with class discussion, I assess whether a student has successfully demonstrated the outcomes. Students complete a course evaluation form on the last day. The evaluation is one designed by librarians and is used in all the LIB classes. It's executed through LibQual. There are three categories with the Likert nine-point scale questions in each and three prompts for open-ended comments. 
Regarding the context for her decision to proceed in this fashion, scanlon writes.

The library had been offering an introductory course, LIB100, since 2003 and I began teaching the class in 2004 shortly after I arrived. In 2009 we started offering a selection of 200-level subject specific classes and I co-developed and taught LIB230 Research Methods for Business and Accounting. In 2013 a student in the 200-level class for the social sciences suggested to the instructor that we should offer a class like that for entrepreneurship students. The instructor mentioned it to me and in 2014, I started teaching ESE305. It was first offered as ESE305 Special Topics in Entrepreneurship, listed among the entrepreneurship classes until it was cleared by the College's Curriculum Committee. The short answer is that the class resulted from a student's suggestion.

2. What factors influenced your decision to proceed on the for-credit class track?

Cramer: Well, the point of the Coleman Fellows program is to create cross-campus (nonbusiness school based) credit classes. So creating and then teaching a credit class was my charge as a new Coleman Fellow. But I also knew there are students on campus interested in a more in-depth exploration of entrepreneurship research than they can get in the feasibility analysis and business plan classes.

Scanlon: The library decided to build on its 100-level information literacy class by offering a menu of subject-specific information literacy classes and in 2009 I began teaching LIB230, a class for business majors. The minor in Entrepreneurship and Social Enterprise has grown into the largest minor at WFU and at a student's suggestion, I developed LIB235 for this cohort.

Each spring semester since 2014, I teach the three-credit ENT/GEO/LIS/MKT 530: "Researching Opportunities in Entrepreneurship \& Economic Development." The class is limited to graduate students and upper-level undergraduates, but otherwise, has no prerequisites.

The basic goal of the class is to help to develop information and data-literate students who can effectively research self-employment and economic development opportunities using authoritative sources. Of course, those research skills would help with future coursework too.

It's an active learning and discussion-based class that meets in a small computer classroom. Students complete seven short research assignments, take a timed midterm exam (the first half on demonstrating core concepts without use of notes, the second half on demonstrating effective and efficient research skills by doing a short research project), present on their capstone research project (on an entrepreneurial idea of their choice), and then write up their capstone research report that incorporates the recommended improvements. There is no final exam. Most students use the capstone to pursue their own entrepreneurial idea, or at least, an industry and market they would like to get a job in. Some pursue a nonprofit idea.

The class began as ENT/GEO/LIS 530, with support and encouragement from the Entrepreneurship program and the Geography and Library \& Information Studies 
departments. After its first year, the head of Marketing asked if a market orders (MKT) cross-listing could be added to provide an elective for students interested in learning secondary research skills.

The biggest change I made after 2014 was to the capstone project description. Originally, I didn't provide a sample outline, preferring to give the students flexibility and even some space for creativity. Some of the undergraduates, however, really struggled with that blank canvas. So in 2015, I provided a detailed suggested outline, which worked out much better this time.

Given the cross-campus nature of the class, I learned not to assume that all the students understand basic business concepts like "business plan", "profit" and "nonprofits".

My students have represented many majors and life stages. Their feedback has been interesting:

$\circ$ rigorous;

- definitely a challenge;

- I had no idea you could get information like this!

- I have really enjoyed your class, you do a great job getting everyone involved and it;

- really makes it easier to learn the material that way; and

- in terms of the sheer volume of practical skills learned, this is one of the best classes I've had.

One graduate student didn't like having to turn her capstone presentation into a final capstone report; she thought that was unnecessary work. That student did a great job on her presentation and didn't need to any significant additional research for the report; so, I understand her point of view. But some students really need the presentation feedback and a chance to do better on the report. So I haven't changed the two-step aspect of the capstone.

Another student provided constructive criticism of the lack of in-class discussion of the assigned reading - a valid comment. I tried to do better with that this year.

3. What feedback or support has business school faculty or administrators provided for the classes?

Cramer: The head of the Marketing department asked that MKT be added as a fourth crosslisting. He wanted marketing majors to have an option for learning secondary research skills. I took that request as a vote of confidence!

Scanlon: The Director of the entrepreneurship program in the College has been very supportive of the class. When I first proposed the idea, she suggested I teach it as a special topics class, while I awaited approval of the Curriculum Committee to make it a permanent class. Thus, it was first listed as ESE 305, but now it is LIB 235 since its approval as a full time class. In the School of Business, the BEM faculty is supportive, and I rely heavily on the School of Business registrars who promote the class to BEM majors and register them for it. 
4. Have the classes changed since first offered, and if so, how and why?

Cramer: Based on student feedback, I'm now more careful about assuming knowledge of business concepts. For example, one student didn't know what a business plan was. So I spend more time defining the core concepts. The biggest change I made was providing a detailed suggested outline for the final presentation and written report. Originally, I wanted to give the students flexibility in how they organized their research, and certainly different types of entrepreneurial ideas may require different mixes of research. However, some students struggled with that freedom and needed help deciding what research to include. So now, I give them the detailed outline.

Scanlon: I never teach the class exactly the same way twice. I revise it every semester based on two different sources. The first is student feedback; I get during class and in the course evaluations. The second source is WFU's Teaching Learning Center (TLC) that offers classes on designing and teaching classes. I've attended classes on everything from how to write a syllabus to how to conduct the first and last days of class. The TLC classes have been a regular source of ideas for revising the class.

5. Reflecting on your experience in and out of the classroom - what are the most common information, reference and research needs of today's entrepreneurs?

Cramer: In terms of secondary research, I think the core research needs of entrepreneurs include local and national industry analysis, competitive intelligence, market identification and sizing and financial benchmarking. The emphasis there has to be on local or regional data in most cases - often much harder to find than national numbers. Most UNCG students work on "Main Street" ideas, and not on business models that assume an immediately national reach.

Statistical literacy is really important. Entrepreneurs need to be able to find the most specific information possible by industry classification (six-digit NAICS is often not good enough), consumer spending categories, etc.

Many entrepreneurs also need to know when primary research is necessary. For example, you can't establish local, current start-up costs using the standard sources for financial ratios. For start-up costs, you need to look up local real estate rental costs, local utility and insurance rates, cost of equipment from local providers, etc. Librarians sometimes over-emphasize the value of secondary research for entrepreneurs.

But "How will my business get funded?" is maybe the most important information need. Also really important: "What is my unit sales driver?" The financials should start from that question, not from financial ratios or even Bimini. Those secondary sources for financial benchmarks should be used as checks again the first draft of one's income statement and balance sheet. 
Entrepreneurs also need to learn about the different types of business incorporations available in their states and the related tax implications. They also need to know the support resources and services (e.g. SCORE or other mentors; the local public library) are available in the community.

Scanlon: Market research is the most commonly sought information from today's entrepreneurship students. They need to identify, describe and locate their potential customers, understand trends in their product or service categories and identify competitors' offerings and activities.

6. In terms of best practices, how might you advise "newbies" (new academic business librarians, new subject liaisons, etc.) to design instructional services, to meet the needs of today's student, faculty, community and veteran entrepreneurs?

Cramer: Get involved anyway you can. Offer to help. If you need a starting point, ask to sit in on some classes; then start speaking up! Most entrepreneurs and entrepreneurship faculty don't know much about the free and proprietary research tools available and would welcome an expert to provide authoritative yet friendly advice and training. Supporting entrepreneurs and entrepreneurial students is economic development and community engagement work, both increasingly important to public and academic libraries.

There isn't too much written about teaching entrepreneurship credit courses, but there are a growing number of business librarians teaching some type of credit course. Network with them online or in person. There was a business librarian get-together at LOEX last year. Mary and I talk about this stuff periodically over lunch or while carpooling to BLINC workshops. BRASS sometimes has online discussions that focus on teaching.

Become the local expert in data sources, both free and subscription-based. Librarians can really shine when they become experts in data and sources that many folks don't know how to use (e.g. American Factfinder). I groan when I hear librarians say stuff like "We don't use Simply Map - it's too confusing of an interface". No it's not - we have freshmen with no geographic information systems (GIS) experience who use it - and you are letting down your own patrons and limiting your own success with that attitude.

Entrepreneurship research requires many kinds of information. If your budgets are tight (as they have been at UNCG), don't be afraid to cancel databases that duplicate content. Know what is most valuable and unique in every business database you provide, and be able to give an elevator pitch on the value of any of them. Tell your head of collections that those databases support campus goals like economic development and community engagement and provide specific examples of how.

Finally, prioritize your time. Teaching credit classes is extremely time-intensive (of course!) but is usually well worth it in the impact on students, information literacy and your relationship with the business school or other stakeholders. Be sure to talk to your department head or director about what your time priorities should be. Is it more useful for 
you to be providing a proactive service via teaching and consulting than to be sitting at the general reference desk every day?

Collect testimonials and success stories regarding your work and don't be afraid to share them. And make sure that the library leaders hear from your entrepreneurship program or business school administrators - regularly, and not just once - of the value you (and by extension the whole library) are contributing to the students and the goals of the university. Those folks could be your library champions.

Scanlon: I would suggest they keep in mind that research is a combination of process and skills. They'll need to teach both. Second, I would advise them that we can't turn our students into librarians in one session or in one class. Making students aware of the resources, we can provide and encouraging them to use our services is part of what I do in the classroom.

7. How is teaching entrepreneurship research different from teaching other kinds of research/business research?

Cramer: That's an interesting question. Those students need a wide array of information (see above), about as wide as it gets for business research. You could almost call it interdisciplinary research! That makes it tough for both the teacher and the students. Yet without plenty of hands-on practice time, students are likely to forget some of the research tools and strategies they have been learning. So you have to balance the need to cover a lot of ground with the need to let the students review what they have learned.

As the class winds down, you can have the students practice their new research skills by starting to making decision based on data. For example, I like having the students consider two different cities for the same proposed business, like a wine bar. One city has no existing wine bar (they will learn using a tool like References or Emergent Intellect) but a small population and lower consumer spending on wine away from home (they will learn using Demographics Now or Simply Map). The other city is much larger, with more consumers spending, but already has wine bars plus many microbreweries and distilleries with tasting rooms (think Asheville, NC). Which is the better location, and why? Students really enjoy that discussion and mini-debate. Being able to debate business decisions based on multiple data points is probably not unique to entrepreneurship research instruction, but is a certainly easier to do than in many other types of classes.

A challenge is that many entrepreneurship students don't have a background in business especially true of the entrepreneurship minors. So you can't assume any previous business knowledge. That was very different for me - Mary too, I think!

On the other head, I love the diverse backgrounds the students bring and enjoy seeing the light bulbs come on in their heads when they learn they can analyze their own target industries or markets. It's also fun to see the dance student bond with the accounting master's student, while the library science student going into art archives becomes a class buddy with the Army veteran entrepreneurship major who is opening up a smoothie shop in town. 
Scanlon: The biggest differences are the targets and the available resources. Business classes usually research-established companies and industries but entrepreneurship classes research new or emerging markets for which there aren't always tidy industry or market research reports. Working with entrepreneurs often means digging for information in lots of different places and stitching it together when no report on an industry or target customer is available.

8. Do you use different resources when teaching in our entrepreneurship programs, or do you use the same resources we use with business majors differently?

Cramer: Hmm, it might really be more about resources to support the experiential learning courses vs the textbook or case study-based classes that really just need books and articles. Marketing and entrepreneurship needs are pretty similar, although the ENT classes do more with financial benchmarking.

Social entrepreneurship is big in many ENT programs, so resources to study nonprofits (like the Web sites that provide IRS 990 forms) are important.

Scanlon: I have two over-arching goals for the class: to teach students about library and other reliable sources; and the process for doing research in the context of a budding enterprise. Thus, as I plan my class, I select young industries but those well enough established that a full complement of library resources is available including industry and market research reports. As a result, there's a lot of overlap with the resources used in my business research class.

In working with students who are developing their own businesses, we have to turn to other resources since industry and market research reports are less likely to be available, but also because the student entrepreneurs need more local information. Resources such as American Factfinder, County Business Patterns and SimplyMap play a bigger role in this instance, although we still use content from library resources, as well.

9. Given your experience in the classroom - how are entrepreneurship majors/students different from other types of students?

Cramer: For the undergraduates, more entrepreneurship students are nontraditional (e.g. military veterans). Maybe more ethnically diverse and more first-generation students? (That would be interesting to study.) A high percentage work many hours a week to support themselves and pay for school, even higher than normal at UNCG.

We joke that the entrepreneurship students are in general hardly the brainiest students on campus, but are more likely to start up something they are passionate about. Sometimes they drop out of school for a semester or two to work on some idea they want to try out! I don't think an accounting or finance student is as likely to do that.

Many entrepreneurship graduates continue to need access to research tools, but aren't going to be working at big companies that provide their own corporate subscriptions to databases. 
So ENT students need to know their options for database through the public library, any alumni database access provided by their old campus library, or other access option. The information literacy frame that "information has value" (and can be expensive) is an idea many ENT students already know.

Scanlon: Students pursuing the minor in ESE are mostly liberal arts majors in the College rather than students in the School of Business. As such, they possess the characteristics of liberal arts students; they're curious, interested in the material, challenging, good problemsolvers. Entrepreneurship students from whichever program engage with the material and are more creative at applying information to the cases. I seem to get better class discussions in LIB 235 than LIB 230, but I can't explain why.

10. What is your perspective on the evolving role of the academic business librarian?

Scanlon: It's become much less about building print collections and much more about supporting curriculum through database selection, instruction and personal research sessions. It's about engaging with faculty and getting involved with any research they may be planning, sometimes offering suggestions on how to modify the assignment based on the available resources.

Cramer: Oh, I agree with Mary. Building relationships with students, faculty and the heads of Entrepreneurship and business programs is key. So the academic business librarian needs to embrace proactive engagement with his or her stakeholders. Business librarians who do that will be in high demand. Both Mary and I dominate the personal research session/consultation statistics at our libraries.

11. On entrepreneurship liaison work?

Cramer: Hmm well if your entrepreneurship major or minor attracts students from across campus, the entrepreneurship librarian might end up be working with arts, science, and social work students as well as business students. I like working with that diversity. But then the entrepreneurship librarian should be careful not to step other liaisons' toes as he/she provides service across campus.

Scanlon: I haven't seen much difference between the role and process for supporting entrepreneurship and business programs.

12. On business librarianship and entrepreneurial outreach?

Cramer: Yes, some of the public librarians are doing very interesting outreach work. For academic librarians, there may be opportunities to work with a campus' entrepreneurship center or office of technology transfer. Providing outreach to campus service centers is a growth area.

Scanlon: Through membership in BLINC, a section of the North Carolina Library Association, I 've gotten to know my colleagues across the state. The public librarians are 
doing much more outreach to local businesses and economic development agencies than I do. They're active in their communities, doing outreach to governmental and non-profit agencies supporting regional economic development, as well as entrepreneurs and small business owners. Several have started visiting businesses as part of their outreach, rather than waiting for the business owners to come to the library. This is a completely different service model than we've seen before.

13. What do you perceive as the challenges of stepping out into this space?

Cramer: If you want to be a busy liaison, get involved with faculty in untraditional ways for a librarian and have students grateful to you each semester, consider business librarianship. Both Mary and I have dominated the public service statistics (especially for consultations/personal research sessions) of the liaisons in our libraries.

When business librarians build relationships with faculty and demonstrate their skills and ability, they can accomplish much. Look at Diane Campbell from Rider University as an example of an entrepreneurship librarian who frequently co-authors with faculty in business journals and presents with them at business faculty conferences.

We also can be leaders for information literacy (and data literacy) as we build connections outside the library and advocate for business research skills.

Scanlon: It seems that the need for research assistance is unrecognized by most entrepreneurs and small business owners. Thus, this group doesn't recognize the extent to which libraries and librarians could help them. Once they begin to understand the resources and expertise we can offer, it' s easy to approach them, but for those who haven't yet recognized our value, it can be challenging to get their attention. 